\title{
Adenine and Folic Acid in the Lesch-Nyhan Syndrome
}

\author{
Paul J. Benke [61], Norma Herrick, Lizabeth Smitten, Garolyn Aradine, \\ Ronald laessig, and George J. Wolcot'T
}

McArdle Laboratory, Departınents of Pediatrics and Pathology, and State Laboratory of Hygiene, University of Wisconsin Medical School, Madison, Wisconsin, USA

\begin{abstract}
Extract
Therapy of identical twin males with the enzyme defect of the Lesch-Nyhan (L-N) syndrome was instituted at $12 \mathrm{hr}$ of age with adenine, $10 \mathrm{mg} / \mathrm{kg} / 24 \mathrm{hr}$, administered to one twin and folic acid, $15 \mathrm{mg} / 24 \mathrm{hr}$, to both. At 4 years of age both twins demonstrate delayed neurologic development and spasticity but are less severely affected than most other patients with this disorder. Administered in subsequent studies to two maternal cousins of the twins who had clinical features of the L-N syndrome and absence of erythrocyte hypoxanthine-guanine phosphoribosyltransferase activity were adenine, $10 \mathrm{mg} / \mathrm{kg} / 24 \mathrm{hr}$, adenine, $40 \mathrm{mg} / \mathrm{kg} / 24 \mathrm{hr}$, folic acid, and monosodium glutamate. Low dose adenine had a slight suppressive effect on glycine$1{ }^{14} \mathrm{C}$ incorporation into uric acid; high dose adenine had a strong suppressive effect in the second patient. We conclude that the adenine dose chosen for therapy was too low. 2,8-1)ihydroxyadenine, a toxic breakdown product of adenine, was detected in the urine at both adenine dose levels. Folic acid and monosodium glutamate in these patients further stimulate accelerated glycine- $1{ }^{14} \mathrm{C}$ incorporation into uric acid.

In vitro transport studies, performed with inverted hamster jejunal preparations, suggest that adenine is largely converted to adenine monophosphate when exposed to the mucosal surface. This may limit the passage of orally administered adenine to the central nervous system in patients. Adenine and purine precursors affect the biochemical pathology of the L-N syndrome, in vivo and in vitro, but therapeutic use of adenine, $10 \mathrm{mg} / \mathrm{kg} / 24 \mathrm{hr}$, and folic acid started on the 1 st day of life did not prevent central nervous system dysfunction.
\end{abstract}

\section{Speculation}

Variation in clinical presentation occurs in the Lesch-Nyhan syndrome. Although small therapeutic benefit may be ascribed to folic acid therapy in our patients, this is not established with certainty. A different approach may be required to prevent central nervous system disease in patients treated from birth.

\section{Introduction}

Patients with severe deficiency of hypoxanthine-guanine phosphoribosyltransferase (EG. 2.4.2.8; H-G
PRT) activity demonstrate hyperuricemia and the gross neurologic signs and symptoms of the Lesch-Nyhan syndrome, including mental retardation, choreoathetosis, spasticity, and self-mutilation $[26,45]$. 
The gene locus for H-G PRT is on the X-chromosome $[30,41]$, and all affected patients identified to date have been males. In 1968 the prenatal diagnosis of H-G PRT deficiency was suggested in the 2nd trimester of pregnancy in a fetus at risk by the failure of cultured amniotic cells to incorporate tritiated hypoxanthine into nucleic acids [12]. More recently, earlier identification of mutant amniotic fibroblasts in similar situations has provided diagnostic information which has led to abortion of an enzyme-deficient fetus [7, 50]. However, this approach may not be elected in some patients, and it was not possible in our situation, in which fetal cells with a mutant enzyme were identified late in pregnancy. Some evidence was available in 1968 to suggest that it was possible to affect abnormalities of cells with mutant H-G PRT in culture with adenine and folic acid [14]. The enzyme defect of the L-N syndrome was confirmed in identical twin males by H-G PRT assay of cord blood hemolysates. This event provided a unique opportunity to study the potential benefits of a new approach to this disorder in subjects at risk of developing severe neurologic discase. This report describes our therapeutic experience with these twins as well as related studies on the biochemical pathology of the disorder.

\section{Methods}

\section{Case Report}

Twin males were born to a known heterozygous carrier for H-G PRT deficiency after an uneventful pregnancy. The mother was a member of a large family with at least 15 affected maternal male relatives with the L-N syndrome [41]. Diagnosis of a mutant fetus was suggested by study of cultured amniotic fluid fibroblasts at 5 months gestation [12]. A single chorion and double amnion were noted at birth, which suggested monozygotic twins, and this was confirmed by blood group testing. Birth weight of twin $A$ was $2.7 \mathrm{~kg}$ and of twin $B$ was $1.6 \mathrm{~kg}$. Delivery of $\operatorname{twin} A$ was uneventful; twin $B$ was a breech presentation with a nuchal cord. Twin $B$ had a 1-min Apgar of 2 and required tracheal intubation to establish normal breathing. He was less vigorous than twin $A$, and at $6 \mathrm{hr}$ of age, hypoglycemia (Dextrostix, $20 \mathrm{mg} / 100 \mathrm{ml}$ ) was noted after an episode of apnea. Appropriate amounts of glucose were administered intravenously. Oral adenine therapy, $10 \mathrm{mg} / \mathrm{kg} / 24 \mathrm{hr}$, in twin $A$ and folic acid, $15 \mathrm{mg} / 24 \mathrm{hr}$, in divided doses in both twins was begun at $12 \mathrm{hr}$ of age. Neurologic examination was not remarkable in either twin at birth. Cord blood uric acid values were $12 \mathrm{mg} / 100 \mathrm{ml}$. At $12 \mathrm{hr}$ of age blood uric acid values were $17.7 \mathrm{mg} / 100 \mathrm{ml}$ in twin $A$ and 16 $\mathrm{mg} / 100 \mathrm{ml}$ in twin $B$. Sodium bicarbonate, $0.9 \mathrm{~g}$ with feedings, was given to maintain the urine $\mathrm{pH}$ at 7.0. Vitamin $\mathrm{B}_{12}, 10 \mu \mathrm{g}$, was given monthly by intramuscular injection to both twins. Blood uric values were frequently normal in the first months of life, but became elevated $(7-9 \mathrm{mg} / 100 \mathrm{ml})$ at 4 months of age. Allopurinol therapy, $50 \mathrm{mg} / 24 \mathrm{hr}$, was then begun.

Growth in height and weight progressed steadily during the 1st year, but dropped below the 3rd percentile in both twins during the 2nd year. Developmental milestones were relatively normal to age 8 months. Subsequent language, social, and motor development have shown continued progress, but have been delayed, as shown in Table I. Both twins had onset of muscle spasticity in the 1st month and both developed signs and symptoms resembling spastic cerebral palsy in the 1st year. Both twins demonstrated persistence of primitive reflexes such as the Moro and tonic neck responses into the 2 nd year life. Twin $A$ has better muscle control than twin $B$. Both twins have received physical therapy. Both twins do not walk except in a walker. Twin $B$ has been easily frustrated and demonstrated some lip mutilation at 3 years 8 months of age. An estimate of I.Q. at age 4 years was 86 and 71 for twins $A$ and $B$ by the Peabody picture vocabulary, and 76 and 70 for twins $A$ and $B$ by the Stanford-Binet test. The twins look alike at age 4 years.

\section{Rationale of Therapy}

In 1968 Marks et al. [29] demonstrated that control of hyperuricemia with allopurinol begun in the neonatal period in an effected patient did not alter the development of the L-N syndrome. We knew that adenine and folic acid enabled fibroblasts to grow in limiting media [14] and that adenine has renal toxicity in rats [34]. It was then decided to treat both twins with folic acid and twin $A$ with adenine to test the hypothesis that one or both of these materials, started at birth, would affect development of central nervous system dysfunction. Use of allopurinol was avoided until required at 4 months of age for control of hyperuricemia because of a suggestion that the accelerated purine synthesis and high cerebrospinal levels of hypoxanthine and xanthine were responsible for central nervous system symptoms [39].

\section{Biochemical Studies}

Hypoxanthine- $8-{ }^{14} \mathrm{C}$, adenine $-{ }^{14} \mathrm{C}$, and glycine $-1-{ }^{14} \mathrm{C}$ were obtained from New England Nuclear Corpora- 
tion [52]. Magnesium phosphoribosyl pyrophosphate (PRPP) and 2,8-dihydroxyadenine (2,8-DHA) were obtained from P-L Biochemicals [53] and Aldrich [54], respectively. Adenine was purchased from Calbiochem [55]. All reagents were the highest grade available.

Blood uric acid values were determined on submicro Unopette samples of capillary blood by a colorimetric techique [24]. Urinary uric acid was determined by enzymatic assay [35]. Adenine phosphoribosyltransferase (A-PRT) and H-G PRT were determined by the method of Kelley et al. [23], which employs high voltage electrophoresis with $0.05 \mathrm{M} \mathrm{pH} 9.0$ boric acid to separate labeled nucleotide product from purine base.

Erythrocytes were washed three times in phosphatebuffered saline, frozen and thawed three times, and dialyzed for $2 \mathrm{hr}$ against $0.005 \mathrm{~m}$ Tris, $\mathrm{pH}$ 7.4. Heat stability studies were performed by incubation of dialyzed erythrocyte hemolysates at $57^{\circ}$ for various periods of time and assayed for A-PRT as described above.

Two male maternal cousins of the twins with the $\mathrm{L}-\mathrm{N}$ syndrome and almost complete $\mathrm{H}-\mathrm{G}$ PRT deficiency were available for study at the Central Wisconsin Colony, Madison, Wisconsin. A 70-g protein diet, essentially free of purines, was started 1 week before glycine radiochemical injection and continued for the duration of the study. In a control study, $2 \mu \mathrm{Ci} / \mathrm{kg}$ glycine- $1{ }^{14} \mathrm{C}$ was injected intravenously and uric acid${ }^{14} \mathrm{C}$ was isolated from the urine by repeated precipitation after addition of cold carricr [46]. Isolated uric acid was solubilized in Hyamine, added to Scintisol, and radioactivity was determined with a Packard liquid scintillation counter [56]. Subsequent studies and injection of glycine- $\mathrm{I}^{-14} \mathrm{C}$ were done at 16 -day intervals. Oral monosodium glutamate (MSG), $4 \mathrm{~g} / 24 \mathrm{hr}$, in one patient and folic acid, $40 \mathrm{mg} / 24 \mathrm{hr}$, by intramuscular injection in the second patient were begun $12 \mathrm{hr}$ before a second glycine- ${ }^{-14} \mathrm{C}$ injection. Oral adenine, 10 $\mathrm{mg} / \mathrm{kg} / 24 \mathrm{hr}$, in one patient and adenine, $40 \mathrm{mg} / \mathrm{kg} /$ $24 \mathrm{hr}$, in the second patient were begun 3 days before a third glycine-1-14 $\mathrm{C}$ injection.

Adenine is probably converted to the toxic metabolite, 2, 8-DHA, by xanthine oxidase. Concentrated hydrochloric acid was added to urine samples until the $\mathrm{pH}$ reached 1.5. Acidified centrifuged urine (0.2-1.0 cc) was placed on a column $(1.5 \times 10 \mathrm{~cm})$ of Dowex $50 \mathrm{~W}-\mathrm{X} 12,200-400$ mesh, and washed with $60-100 \mathrm{ml}$ $0.5 \mathrm{~N} \mathrm{HCl}$. The 2,8-DHA was eluted with a linear $0.5-6.0 \mathrm{~N} \mathrm{HCl}$ gradient and determined by absorption at $305 \mathrm{~m} \lambda$ optical density [34].

A modification of the Crane and Wilson inverted jejunum technique [9] was used to study adenine intestinal transport. A hamster, which weighed $90 \mathrm{~g}$, previously cycled in a $12 \mathrm{hr}$ light- $12 \mathrm{hr}$ dark room, was decapitated and a length of clistal jejunum adjacent to the cecum removed. The jejunum was rinsed free of feces with an isotonic saline solution containing $0.5 \%$ glucose, and everted with a plastic rod. The proximal encl was tied to a glass cannula with a rubber stopper containing two 18-gauge needles. The first needle served as a vent and the second was attached to tubing for oxygen. The inverted intestine was tied, filled with

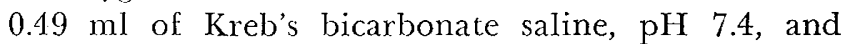
placed in a test tube filled with Kreb's bicarbonate saline to a height $1 \mathrm{~cm}$ below the pressure head of the serosal fluid to prevent the collapse of the sac. The sac was allowed to equilibrate for $15 \mathrm{~min}$ in a $37^{\circ}$ shaking water bath with an oxygen flow rate of 140 bubbles/ min. Oxygen flow was adjusted and maintained via individual thumb screws; preliminary studies demonstrated close regulation of oxygen flow rate was necessary to obtain consistent results. After equilibration, alanine ${ }^{-14} \mathrm{C}$ or adenine $-{ }^{14} \mathrm{C}$ were introduced in the test tube on the mucosal surface. Samples of $20 \mu \mathrm{l}$ each from the serosal sac were taken at intervals up to 34 min postequilibration. Samples were brought up to a total volume of $0.9 \mathrm{ml}$ with double-distilled water. Scintisol was added and samples were counted by liquid scintillation. Serosal fluid was drained from the gut sac, frozen, and lyophilized and thin layer chromatography was performed as described below. The intestine was rinsed in cold Kreb's bicarbonate saline, blotted on Whatman filter paper, and weighed in the cold room. Nine volumes $(w / v)$ of Kreb's buffer at $0^{\circ}$ were adcled to intestine which was minced and homogenized in a Potter-Elvejhem homogenizer. Homogenates were precipitated with perchloric acid [18] and centrifuged at 2,000 rpm at $4^{\circ}$. The supernatant was lyophilized, neutralized with $\mathrm{KOH}$, and thin layer chromatography was performed on polyethyleneimine chromatography to measure AMP levels [18] and by two-directional cellulose chromatography to measure adenine levels [8].

\section{Results}

\section{Evaluation of Therapy}

Patients with the L-N syndrome develop normally for the first months of life [31, 32]. Our patients had an unusually early onset of spasticity as shown in Table I. It can not be determined at present whether this was due to the nutritional stress of twin birth, an 
Table I. Developmental milestones of twins

\begin{tabular}{|c|c|c|}
\hline & Twin $A$ & Twin $B$ \\
\hline \multicolumn{3}{|l|}{ Gross motor } \\
\hline Onset of spasticity & 1 mo & 7 days \\
\hline Sit with support & $5.5 \mathrm{mo}$ & $5.5 \mathrm{mo}$ \\
\hline Sit without support & $3 \mathrm{yr}$ & $3 \mathrm{yr}$ \\
\hline Get into sitting position & 3 yr 4 mo & 3 yr 9 mo \\
\hline Crawl in disorganized pattern & $8 \mathrm{mo}$ & $8 \mathrm{mo}$ \\
\hline Crawl in reciprocal pattern & $34 \mathrm{mo}$ & $34 \mathrm{mo}$ \\
\hline Crawl on four points & 3 yr 4 mo & 3 yr 9 mo \\
\hline Roll both ways & $9 \mathrm{mo}$ & 9 mo \\
\hline Stand using support & $7 \mathrm{mo}$ & $7.5 \mathrm{mo}$ \\
\hline $\begin{array}{l}\text { Walk in walker, feet hypercx- } \\
\text { tended }\end{array}$ & $10 \mathrm{mo}$ & $10 \mathrm{mo}$ \\
\hline \multicolumn{3}{|l|}{ Fine motor } \\
\hline Whole hand grasp & $7 \mathrm{mo}$ & $7 \mathrm{mo}$ \\
\hline Transfer objects & $8 \mathrm{mo}$ & $10 \mathrm{mo}$ \\
\hline \multicolumn{3}{|l|}{ Personal-social } \\
\hline Drink from cup & $11 \mathrm{mo}$ & $11 \mathrm{mo}$ \\
\hline Feed self & 3 yr $4 \mathrm{mo}$ & \\
\hline Toilet trained & 3 yr 4 mo & 3 yr 9 mo \\
\hline Lip-biting mutilation, mild & & 3 yr $8 \mathrm{mo}$ \\
\hline \multicolumn{3}{|l|}{ Language } \\
\hline Mama, Dada & $10 \mathrm{mo}$ & $10 \mathrm{mo}$ \\
\hline Several words & $12 \mathrm{mo}$ & $12 \mathrm{mo}$ \\
\hline 10-15 Word vocabulary & $22 \mathrm{mo}$ & $22 \mathrm{mo}$ \\
\hline Sentences with little dysarthria & $3 \mathrm{yr}$ & \\
\hline $\begin{array}{l}\text { Indicate body parts, recognize } \\
\text { objects }\end{array}$ & $2-3$ yr & $2-3 \mathrm{yr}$ \\
\hline Follow directions & $2-3 \mathrm{yr}$ & $2-3$ yr \\
\hline
\end{tabular}

artificial bias created by close patient observation during this time, or other reasons. Low birth weight, nuchal cord, neonatal hypoglycemia, and respiratory distress may have affected the subsequent development of $\operatorname{twin} B$; this is more likely responsible for the slower attainment of milestones than the administration of adenine, $10 \mathrm{mg} / \mathrm{kg} / 24 \mathrm{hr}$, to twin $A$.

The twins demonstrate milder central nervous system symptoms than any of their 15 maternal cousins affected with the disease, most of whom died of pneumonia or renal failure at different ages before the clinical entity was identified in 1964 [26]. The twins demonstrate milder symptoms than seven of our patients from four other families which are unrelated as well as can be determined [5]. Developmental milestones listed in Table I appear better than other patients described who generally do not sit up, speak in sentences without dysarthria, feed themselves, or become toilet trained [31, 32]. Folic acid may have been of some therapeutic use, although spasticity and delay in the gross motor development are evident. The problem in assessing a therapeutic result in these patients is that variation occurs in clinical presentation of the disease, even among families [5, 31, 32]. Some patients may have near normal intelligence [43]. It is unfortunate that similar developmental milestones are not available for our own and for other affected patients. Physical therapy may have assisted in attaining some milestones listed in Table I. Aggressive compulsive behavior has not been noted in our twins as it has in almost all other patients [31, 32]. However, twin $B$ recently chewed his lip a few times when frustrated in sibling-rivalry situations.

The mother of the twins received agents to prevent ovulation for over a year before they were discontinued and conception occurred. It has been recently reported that contraceptive agents may lead to folic acid deficiency in the pregnant female [28]; the importance of this factor in our study cannot be determined.

\section{Biochemical Studies}

Assay of erythrocyte H-G PRT in both twins on the 1st day of life was less than $0.01 \%$ of control values with hypoxanthine- $8-{ }^{14} \mathrm{C}$ as substrate. Twenty-fourhour uric acid excretion in the neonatal period was 70 $\mathrm{mg} / \mathrm{kg} / 24 \mathrm{hr}$ in twin $A$ on three occasions and $65-85$ $\mathrm{mg} / \mathrm{kg}$ in twin $B$. Older children excrete $45-55 \mathrm{mg} /$ $\mathrm{kg} / 24 \mathrm{hr}$ [26]. The higher values in younger patients may be secondary to their lower percentage of body weight in connective tissue and bone. Adenine administered by mouth to older patients does not increase 24-hr uric acid excretion [6]. Study of glycine-1-14C incorporation in urinary uric acid in the male maternal cousins with the L-N syndrome were begun when the twins were 8 months old. Daily patterns are given in Figures 1 and 2. Cumulative recovery of the injected radioactivity in urinary uric acid is shown in Table II. It can be seen in Figure 1 that low dose adenine slightly delayed the incorporation of glycine${ }^{1-{ }^{14} \mathrm{C}}$ into urine uric acid and MSG increased incorporation. Figure 2 demonstrates that $40 \mathrm{mg} / \mathrm{kg} / 24 \mathrm{hr}$ adenine suppressed accelerated glycine- ${ }^{14} \mathrm{C}$ incorporation and lowered the pattern to that found in control subjects [46]. Zee et al. [48] have found similar suppression of accelerated purine synthesis with $50 \mathrm{mg} /$ $\mathrm{kg} / 24 \mathrm{hr}$ adenine. Adenine, $10 \mathrm{mg} / \mathrm{kg} / 24 \mathrm{hr}$, was used in therapy of twin $A$, and these studies demonstrate that more adenine is required to suppress purine synthesis. Folic acid and MSG further stimulate the accelerated purine synthesis in affected patients primarily in the first 2 days (Figs. 1 and 2). Further experiments would be required to determine whether these agents lead to a sustained higher level of de novo purine synthesis and whether this is the mechanism of folic 


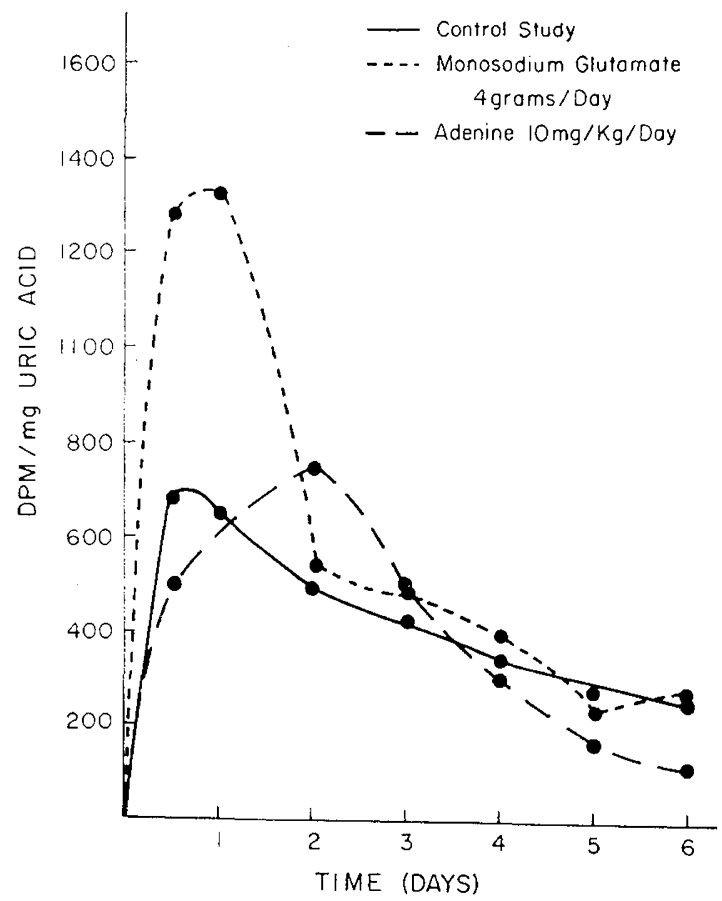

Fig. 1. Effect of monosodium glutamate and low dose adenine on glycine- $1{ }^{11} \mathrm{C}$ incorporation in uric acid in a male maternal cousin with the Lesch-Nyhan syndrome.

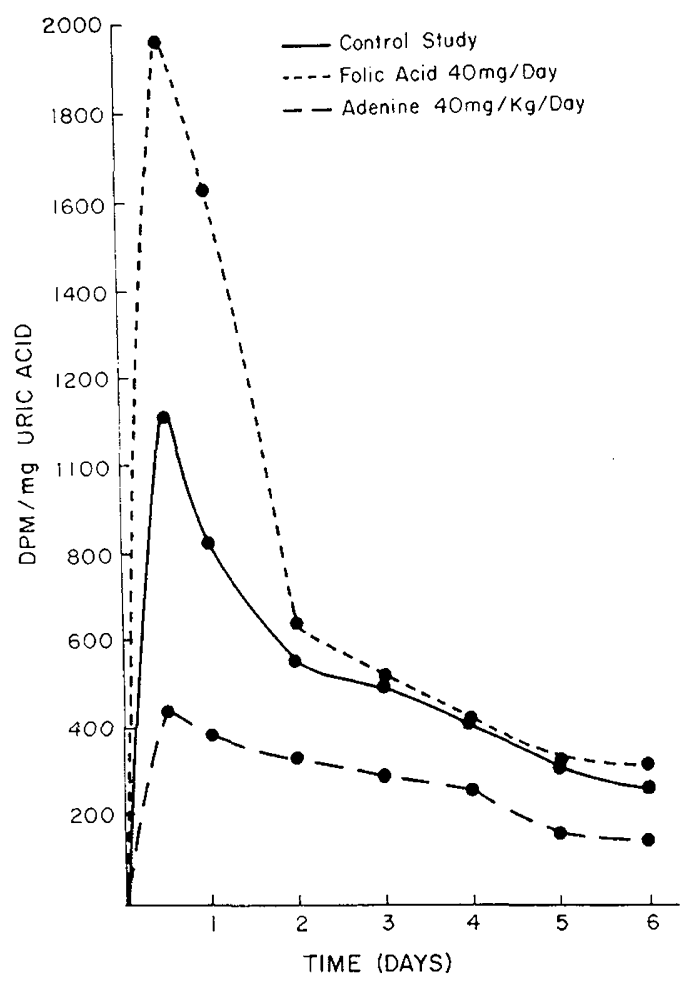

Fig. 2. Effect of folic acid and high dose adenine on glycine-I-14 $\mathrm{C}$ incorporation in uric acid in a second male maternal cousin with Lesch-Nyhan syndrome. acid-facilitated growth of $\mathrm{L}-\mathrm{N}$ fibroblasts in limiting media. Little change is noted in 24-hr urine uric acid levels with folic acid, MSG, and adenine [5, 6]. There is some evidence that suggests fibroblasts from patients with the L-N syndrome have an increased metabolic need for glutamine [36]. Poorly nourished patients may benefit from oral administration of MSG [16]. Adenine-treated patients demonstrate 2,8-DHA in the urine in significant amounts (Table II and Reference 44). 2, 8-DHA is not detected in the urine when allopurinal, a xanthine oxidase inhibitor, is administered [5, 44].

\section{A-PRT Heat Stability}

Patients with the L-N syndrome have increased amounts of a heat-stable A-PRT in erythrocytes [17]. Increased erythrocyte PRPP levels may explain the altered heat stability [17]. Experimental therapy started on the Ist day of life did not affect erythrocyte A-PRT levels in the twins [5]. The A-PRT heat stability at 4 months of age was greater than for control subjects in both twins (Fig. 3) and similar to that in older patients with the L-N syndrome. Adenine, $10 \mathrm{mg} / \mathrm{kg} / 24 \mathrm{hr}$, was

Table II. Summary of effect of adenine, monosodium glutamate, and folic acid on purine metabolism in two male maternal cousins with Lesch-Nyhan syndrome

\begin{tabular}{|c|c|c|c|}
\hline & $\begin{array}{l}\text { Control } \\
\text { study }\end{array}$ & $\begin{array}{c}\text { Mono- } \\
\text { sodium } \\
\text { glutamate, } \\
\text { 4 g/24 hr }\end{array}$ & $\begin{array}{l}\text { Adenine, } \\
40 \mathrm{mg} / \mathrm{kg} / \\
24 \mathrm{hr}\end{array}$ \\
\hline \multicolumn{4}{|l|}{ Patient 1} \\
\hline $\begin{array}{l}\text { Percentage of cumulative re- } \\
\text { covery of glycinc- }-1{ }^{14} \mathrm{C} \text { in } \\
\text { urinary uric acid, } 6 \text { days }\end{array}$ & 1.72 & 2.19 & 1.08 \\
\hline \multirow{2}{*}{$\begin{array}{l}\text { Recovery of } 2,8 \text {-dihydroxy- } \\
\text { adenine in urine, range of } \\
\text { percentage of administered } \\
\text { adenine }^{1}\end{array}$} & 0 & & $2.5-3.8$ \\
\hline & $\begin{array}{l}\text { Control } \\
\text { study }\end{array}$ & $\begin{array}{l}\text { Folic } \\
\text { acid, } \\
40 \mathrm{mg} / \\
24 \mathrm{hr}\end{array}$ & $\begin{array}{l}\text { Adenine, } \\
10 \mathrm{mg} / \mathrm{kg} / \\
24 \mathrm{hr}\end{array}$ \\
\hline \multicolumn{4}{|l|}{ Patient 2} \\
\hline $\begin{array}{l}\text { Percentage of cumulative re- } \\
\text { covery of glycine- }-1-{ }^{14} \mathrm{C} \text { in } \\
\text { urinary acid, } 6 \text { days }\end{array}$ & 1.69 & 1.91 & 1.61 \\
\hline $\begin{array}{l}\text { Recovery of } 2,8 \text {-dihydroxy- } \\
\text { adenine in urine, range of } \\
\text { percentage of administered } \\
\text { adenine }\end{array}$ & 0 & & $1.4-4.0$ \\
\hline
\end{tabular}




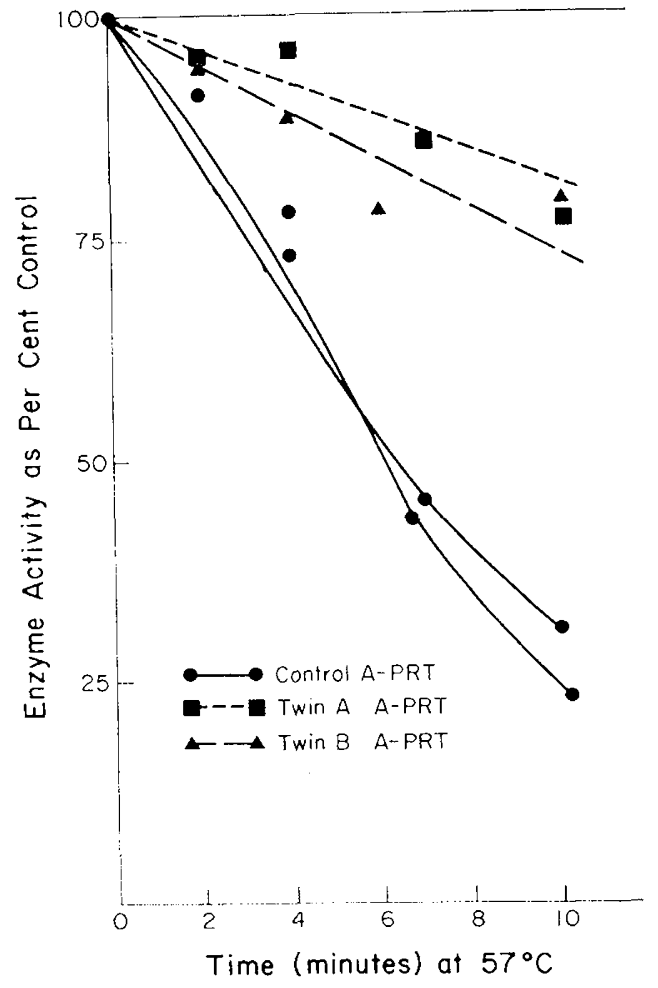

Fig. 3. Heat stability of adenine phosphoribosyltransferase $(A-P R T)$ from control and patient erythrocytes hemolysates studied when the twins were 4 months old.

probably not sufficient to lower erythrocyte PRPP levels in $\operatorname{twin} A$.

\section{Inverted Hamster Jejunal Transport}

Although the inverted jejunal technique has been widely used for transport studies, it suffers the disadvantage that it measures the nonphysiologic passage of test compounds from intestinal mucosal to serosal surface. We have used this technique to assess relatively the transport of adenine and alanine. That adenine passage into the serosal sac is proportional to its concentration on the muscosal surface, but passage is poor when compared with alanine, is demonstrated in Figure 4. In Table III it may be seen that adenine is largely converted to adenine monophosphate (AMP) in gut homogenates and serosal fluid during passage from the muscosal surface, and although serosal adenine increases with increasing concentration of mucosal adenine, most is converted to AMP. This AMP may not reach the central nervous system since phosphorylated compounds pass cell membranes with difficulty.

\section{Discussion}

The finding that loss of H-G PRT was associated with accelerated purine synthesis and neurologic disease [45] was the first indication that this enzyme was important both in the economy of purine metabolism and in central nervous system development. However, data to explain the relation of the accelerated purine synthesis to the central nervous system dysfunction of the L-N syndrome have been difficult to obtain. Hypotheses to explain hyperuricemia and the development of neurologic dysfunction have been examined in detail $[10,37,44]$. H-G PRT has high activity in fetal brain [1,39], and values rise to the higher values of adult brain shortly after birth [1]. Although enzyme activity is particularly high in basal ganglia [39], pathologic study of the central nervous system in autopsied cases does not reveal specific anatomic lesions [42, 51].

Elevated PRPP levels in $\mathrm{L}-\mathrm{N}$ cells have been impli-

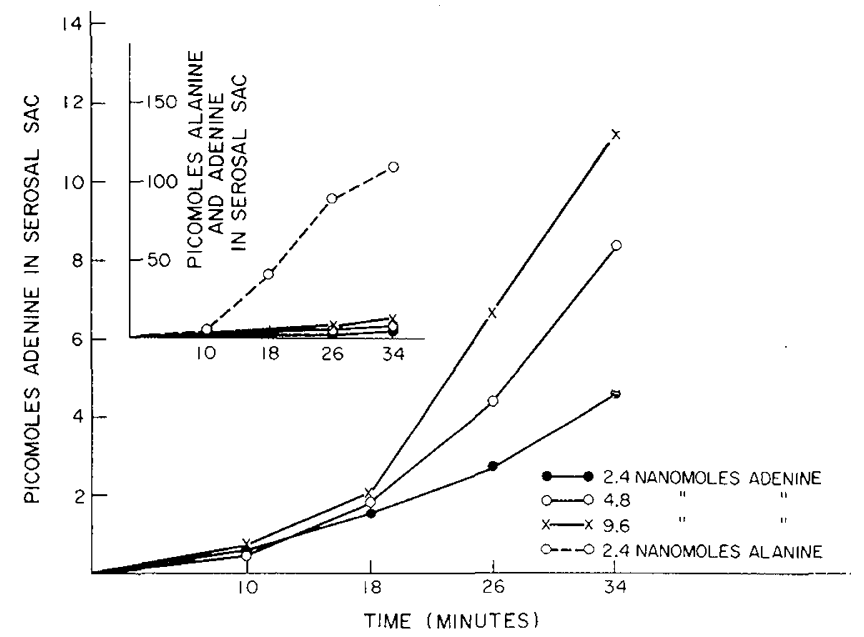

Fig. 4. Transport of adenine $-{ }^{14} \mathrm{C}$ and alanine $-{ }^{14} \mathrm{C}$ from mucosal to serosal surface in inverted hamster jejunum. Adenine transport was proportional to concentration. Passage of adenine was poor compared with alanine (insel).

Table III. Adenine monophosphate (AMP)/adenine ratios obtained with adenine ${ }^{-14} \mathrm{C}$ incubation on mucosal surface of inverted hamster jejunum ${ }^{1}$

\begin{tabular}{ccc}
\hline $\begin{array}{c}\text { Mucosal fuid } \\
\text { adenine concentration }\end{array}$ & $\begin{array}{c}\text { Serosal fluid } \\
\text { AMP/adenine ratio }\end{array}$ & $\begin{array}{c}\text { Gut homogenate } \\
\text { AMP/adenine ratio }\end{array}$ \\
\hline $1.2 \times 10^{-9} \mathrm{M}$ & & $61.7 / 1$ \\
$2.4 \times 10^{-9} \mathrm{M}$ & $106 / 1$ & $11.1 / 1$ \\
$4.8 \times 10^{-9} \mathrm{M}$ & $6.3 / 1$ & $9.2 / 1$ \\
$9.6 \times 10^{-9} \mathrm{M}$ & $2.8 / 1$ & $6.9 / 1$
\end{tabular}

${ }^{1} \Lambda$ bout $0.2 \%$ of labeled compound passed to the serosal fluid in $34 \mathrm{~min}$ at each adenine concentration. 
cated as a cause of accelerated purine synthesis [37, 38], and the accelerated purine synthesis in turn has been offered as an explanation for the neurologic dysfunction [39]. However, PRPP turnover is normal in L-N cells in culture [37, 38]. Patients with levels of $\mathrm{H}-\mathrm{G}$ PRT only slightly higher than those found in L-N erythrocytes and a similar magnitude of accelerated purine synthesis are generally spared central nervous system disease [22]. An alternative hypothesis for accelerated purine synthesis in these patients is that the mutant H-G PRT fails to return hypoxanthine to cellular nucleotides in vivo [47], which leads to release of purine feedback control mechanisms. Toxic or unusual purines have not been found in the urine [5, 31].

Tissues other than the central nervous system must be used in man to study the consequence of loss of H-G PRT activity. The biochemical pathology of erythrocytes and fibroblasts from affected patients may be improved by relatively simple chemical alterations. Older patients with the L-N syndrome occasionally develop megaloblastic anemia [49] associated with low erythrocyte adenine nucleotide levels [27]. The anemia and lowered adenine nucleotides improve with oral adenine therapy [27]. Fibroblasts in tissue culture taken from patients with the $\mathrm{L}-\mathrm{N}$ syndrome do not grow in F4 media, but will grow when adenine or folic acid is added to the culture [14]. The mechanism for this response has not been studied. Our results indicate that opposite effects on de novo purine synthesis may be observed in vivo; adenine, $40 \mathrm{mg} / \mathrm{kg} / 24 \mathrm{hr}$, suppresses and folic acid further stimulates the accelerated purine synthesis (Fig. 2). It is not clear how these materials can exert different effects and nevertheless be of benefit to cells in culture grown in limiting media [14] unless both act to increase cellular nucleotide levels. However, the evidence on this point does not suggest that nucleotide levels are low in L-N fibroblasts in culture, although greater than $70 \%$ decrease in AMP levels have been observed in one L-N cell strain [37]. Studies of cellular nucleotide levels in this cell strain were carried out in nonlimiting Eagle's medium [37], in which the accelerated purine synthesis could compensate for loss of H-G PRT activity. The lowered AMP levels found are probably significant since L-N fibroblasts in culture are more sensitive to adenine inhibition of the first steps of purine synthesis than control cell strains [4, 37, 38].

Orally administered adenine does not alter the clinical expression of older patients with neurologic disease [6]. Adenine in doses up to $60 \mathrm{mg} / \mathrm{kg} / 24 \mathrm{hr}$ did not prevent the development of neurologic symptoms in a 3 -week-old infant [44]. The failure of orally administered adenine to benefit the neuropathology of neonatal patients with the L-N syndrome may be due to poor transport of adenine across the intestinal mucosa (Fig. 4), and the large conversion of adenine to AMP (Table III). Also, serum adenine is largely adsorbed by erythrocytes [33] and other tissues, which allows little to reach the central nervous system [15, 33], even though there is no barrier for the transport of adenine into brain [15]. Some oral adenine, $40 \mathrm{mg} / \mathrm{kg}$, (Fig. 2 and $50 \mathrm{mg} / \mathrm{kg}$ [48]) must reach the liver to suppress de novo purine synthesis.

Blood cells require preformed purines for growth and "salvage" them from liver [25]. However, studies using rats demonstrate that the brain has a well developed capacity for de novo purine synthesis [19, 21] which may amount to $30 \%$ of the liver capacity [21]. Endogenous brain adenine pools appear to be utilized preferentially to intravenously injected adenine- ${ }^{-14} \mathrm{C}$ [19]. These combined studies suggest that the value of H-G PRT to the central nervous system is more to return hypoxanthine to cellular nucleotides than to "salvage" purines from blood.

It can be seen in Figure 5 that for each mole of hypoxanthine not converted to inosine monophosphate (IMP) in enzyme-deficient cells, $4 \mathrm{~mol}$ ATP are consumed to synthesize IMP from simple purine precursors. Neurologic disease in the L-N syndrome may result from (1) diversion of ATP to brain purine synthesis from other important biochemical synthesis, (2) low brain ATP levels at a critical stage of development, (3) central nervous system consumption of important purine precursors. These possibilities are interrelated and not subject to study in patients. The development pathology in the L-N syndrome is similar to that found in some forms of cerebral palsy, although in the latter, the insult to the central nervous system is related to an event which occurred in the distant past. Low blood sugar has been established as one of the etiologies of brain clamage, and Howard et al. [21] have shown that brain purine synthesis in vitro is sensitive to glucose levels. We can only speculate that neonatal hypoxic and hypoglycemic events, which are related to the pathogenesis of some forms of cerebral palsy, lcad to lowered brain ATP levels, and further, that lowered brain ATP levels are related to the developmental pathology of the L-N syndrome. Held et al. [20] have noted that intracerebral injection of aza-L-scrine, an inhibitor of de novo purine synthesis, 


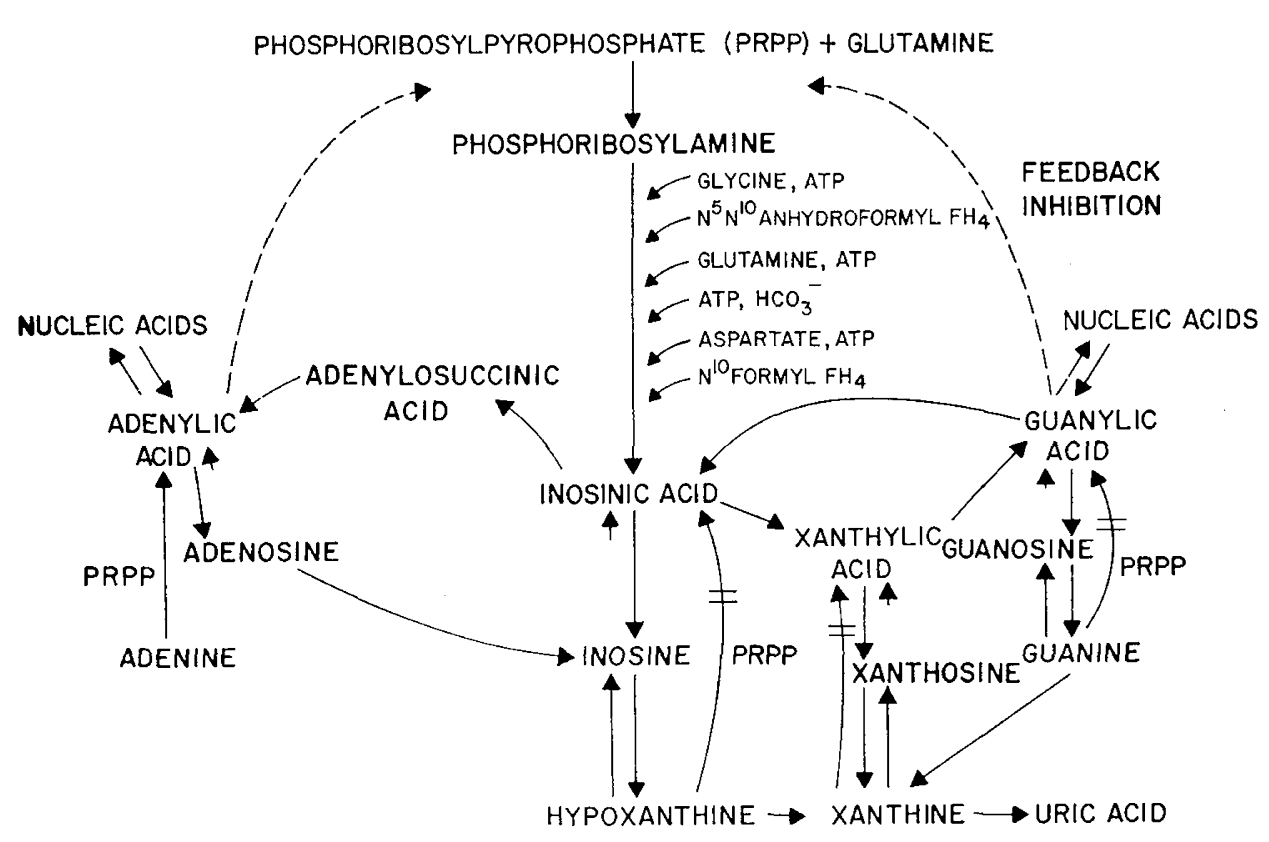

Fig. 5. Pathways of purine metabolism. Loss of hypoxanthine-guanine phosphoribosyltransferase activity leads to trapping of degraded adenine nucleotides in hypoxanthine (47) which is normally an active cellular metabolite. Accelerated purine synthesis consumes important purine precursors, including formyl groups carried by folic acid $\left(\mathrm{FH}_{4}\right)$.

in rats leads to rapidly lowered cerebral ATP levels. This is followed by transient spastic paraplegia [20] and suggests that failure to meet central nervous system purine requirements may lead to neurologic symptoms.

We have emphasized above that our patients had an unusually early onset of spasticity, perhaps because of larger in utero nutritional requirements created by twins. However, as recorded in Table I, the twins have some motor skills not recorded in reports of other patients with the disorder $[26,31,32]$. These results cannot be ascribed to adenine, which was administered to one twin in an amount too low to have significant effect on the accelerated purine synthesis (Fig. 1 and Table II), and are not dramatic enough to claim theraputic efficacy for folic acid. Administration of folic acid to the pregnant mother, higher dose adenine to the patients, and early institution of allopurinol may have improved our therapy. It would be useful to study these problems in a laboratory animal such as the mouse, where an experimental model has been suggested [11], and the gene locus for H-G PRT activity may also be on the X-chromosome [13].

Affected patients have normal immunologic amounts of a catalytically incompetent H-G PRT in erythrocytes and fibroblasts [2, 40], and extracts of normal H-G PRT may activate the mutant enzyme [3].
We have obtained evidence recently that mutant H-G PRT enzymes in L-N cells are activated by magnesium ions in culture [5]. These findings may lead to the development of new theraputic approaches for infant patients at risk for this clisorder.

\section{Summary}

Adenine, $10 \mathrm{mg} / \mathrm{kg} / 24 \mathrm{hr}$, and folic acid started on the 1st day of life, did not prevent the development of the L-N syndrome in identical twin males. The adenine dose chosen was too low to significantly affect $d e$ novo purine synthesis. Other studies suggest that a higher dose of adenine suppresses and folic acid stimulates the accelerated purine synthesis. Adenine is converted to the mononucleotide by inverted hamster intestinal preparations, and little orally administered adenine may reach the brain in patients.

\section{References and Noles}

1. Adans, A., Anderson, J. M., Nicol., A. D., and Harkness, R. A.: The development of hypoxanthine/guanine phosphoribosyltransferase activity in man. Biochem. J., 125: 36P (1971).

2. Arnold, W. J., Meade, J. C., and Kelley, W. N.: Hypoxanthine-guanine phosphoribosyltransferasc: Characteristics of the mutant enzyme in erythrocytes from patients with the Lesch-Nyhan syndrome. J. Clin. Invest., 51: 1805 (1972).

3. BAKAY, B., AND NYHAN, W. L.: Activation of variants of 
hypoxanthine-guaninc phosphoribosyl transferase by the normal enzyme. Proc. Nat. Acad. Sci. U. S. A., 69: 2523 (1972).

4. Binke, P. J., and Herrick, N.: Azaguanine-resistance as a manifestation of a new form of metabolic overproduction of uric acicl. Amer. J. Med., 52: 547 (1972).

5. Benke, P., And Herrick, N.: Unpublished data.

6. Berman, P. H., Balis, M. E., and Dancis, J.: Congenital hyperuricemia. Arch. Neurol., 20: 44 (1969).

7. Boyle, J. A., Rayvio, K. O., Astrin, K. H., Schulman, J. D., Graf, M. L., Seegmilifer, J. E., and Jacobsen, C. B.: LeschNyhan syndrome: Preventive control by prenatal diagnosis. Science, 169: 688 (1970).

8. Crabtree, G. W., and Hfnderson, J. F.: Rate-limiting steps in the interconversion of purine ribonucleotides in Ehrlich ascites tumor cells in vitro. Cancer Res., 31: 958 (197l).

9. Crane, R. K., and Wrison, T. H.: In vitro method for the study of the rate of intestinal absorption of sugars. J. Appl. Physiol., 12: 145 (1958).

10. Crawhall, J. C., Henderson, J. F., and Kelley, W. N.: Diagnosis and treatment of the Lesch-Nyhan syndrome. Pediat. Res., 6: 504 (1972)

11. DFMArs, R.: Genetic studies of H-G PRT deficiency and the Lesch-Nyhan syndrome with cultured human cells. Fed. Proc., 30: 944 (1971).

12. Dfmars, R., Sarto, G., Felix, J., and Benke, P.: Lesch-Nyhan mutation: Prenatal detection with amniotic fluid cells. Science, 164: 1303 (1969).

13. Epstein, C. J.: Expression of the mammalian X-chromosome before and after fertilization. Science, 175: 1467 (1972).

14. Fer.rx, J. S., and DeMars, R.: Purine requirement of cells cultured from humans affected with Lesch-Nyhan syndrome (hypoxanthine-guanine phosphoribosyltransferase deficiency). Proc. Nat. Acad. Sci. U. S. A., 62: 536 (1969).

15. FORD, D, H., AND RHINES, R.: $\mathrm{H}^{3}$ accumulation in spinal cord ncurons following intravenous injection of adenine- $\mathrm{H}^{3}$. Acta Neurol. Scand., 43: 427 (1967).

16. Ghamimi, H.: The significance of the deficiency state in LeschNyhan Disease. Acta Pacdiat., 59: 233 (1970).

17. Griene, M. L., Boyle, J. A., and Sefgmiller, J. E.: Substrate stabilization: Genctically controlled reciprocal relationship of two human enzymes. Science, 167: 887 (1970).

18. Grifiman, D. L.: Thin-layer separation and quantitative clution of nucleosides and nucleotides. Anal. Biochem., 31: 348 (1969).

19. Her.d, I., AND Wells, W.: Observations on purine metabolism in rat brain. J. Neurochem., 16: 529 (1969).

20. Held, I., Wells, W., and KofNY, H.: Metabolic effects of azaserine in rat brain. J. Neurochem., 16:537 (1969).

21. Hownrd, W. I., Kfrson, L. A., and Appel, S. H.: Synthesis de novo of purines in slices of rat brain and liver. J. Neurochem., 17: 121 (1970).

22. Kfiliey, W. N., Greene, M. L., Rosenbroom, F. M., Henderson, J. F., AND SrFgmiller, J. E.: Hypoxanthine-guanine phosphoribosyltransferase deficiency in gout. Ann. Intern. Med., 70: 155 (1969).

23. Kelit.y, W. N., Rosenbloom, Y. M., Henderson, J. F., and Sefgmiller, J. E.: A specific enzyme defect in gout associated with overproduction of uric acid. Proc. Nat. Acad. Sci. U. S. A., 57: 1735 (1967).

24. Lafssig, R. H., and Basteyns, B. J.: Simultaneous submicro- determination of glucose and uric acid. Microchem. J., J3: 418 (1968).

25. LAJTHA, L. G., AND VANE, J. R.: Dependence of bone maxrow cells on the liver for purine supply. Nature, 182: 181 (1958).

26. Lesch, M., AND Nyhan, W. L.: A familial disorder of uric acid metabolism and central nervous srstem function. Aner. J. Med., 37: 561 (1964).

27. Lommen, E., Vogels, G., van dfr Zee, S., Trijbels, J., and Schretlen, E.: Concentration of purine nucleotides in erythrocytes of patients with the Lesch-Nyhan syndrome before and during oral administration of adenine. Actia Pediat. Scand., 60: 642 (1971).

28. Luhby, A. L., Shimizu, N., Davis, P., ANd Cooperman, J. M.: Folic acid deficiency in users of oral contraceptive agents. Fed. Proc., 30: 239 (1971)

29. Marks, J. F., Baum, J., Keelf, D., Kay, J., and Mackarlen, A.: Lesch-Nyhan syndrome treated from the early neonatal period. Pediatrics 42: 357 (1968)

30. Migeon, B., der Kaoustian, V. M., Nyhan, W. L., Young, W. J., AND CHILDs, B.: X-linked hypoxanthine-guanine phosphoribosyl transferase deficiency: Hcterozygote has two clonal populations. Science, 160: 425 (1968).

31. Nyman, W. L.: Introduction: Clinical and genetic features. Fed. Proc., 27: 1027 (1968).

32. NyHAN, W. L.: Clinical features of the Lesch-Nyhan syndrome. Arch. Intern. Med., 130: 186 (1972).

33. Pakkenberg, H., Ford, D. H., Phines, R., and Israflly, R. A.: Adenine- $\mathrm{H}^{3}$ uptake in nervous tissue. Acta. Neurol. Scand., 41: 497 (1965).

34. Phimips, F. S., Thiersch, J. B., And Bendich, A.: Adenine intoxication in relation to in vivo formation and deposition of 2,8-dioxyadenine in renal tubules. J. Pharmacol., 10t: 20 (1952).

35. Praftorius, E.: An enzymatic method for the determination of uric acid by ultraviolet spectrophotometry. Scand. J. Clin. Lab. Invest., 1: 222 (1949)

36. Raivio, K. O., and Seegmiller, J. E.: Effects of glutamine deficiency on purine metabolism in the Lesch-Nyhan syndrome. Pediat. Res., 5: 396 (1971).

37. Rosenibloom, F. M., Henderson, J. E., Caldwfili, I. C., Kelley, W. N., and Seegmiller, J. E.: Biochemical bases of accelerated purine biosynthesis de novo in human fibroblasts lacking hypoxanthine-guanine phosphoribosyl transferasc. J. Biol. Chem., 243: 1166 (1968).

38. Rosenbloom, F. M., Henderson, J. E.. Kelleey, W. N., and Sefgmitr.f., J. E.: Accelerated purine biosynthesis de nowo in skin fibroblasts deficient in hypoxanthine-guanine phosphoribesyltransferase activity. Biochim. Biophys. Acta, 166: 258 (1968).

39. Rosfenbloom, F. M., Kfi.ley, W. N., Miller, J., Hfyiderson, J. F., ANd Serganlere, J. E.: Inherited disorder of purine metabolism. J. Amer. Med. Ass., 202: 175 (1967).

40. Rubin C. S., Dancis, J., Yre, L. C., Nowrnski, R. C., and BAL.s, M. E.: Purification of MMP: Pyrophosphate phosphoribosyltransferases, catalytically incompetent enzymes in Lesch-Nyhan disease. Proc. Nat. Acad. Sci. U. S. A., 68: 146 (1971).

41. Salzmann, J., DeMars, R., and Benke, P.: Single-allele cxpression at an $\mathrm{x}$-linked hyperuricemia locus in heterozygous human cells. Proc. Nat. Acad. Sci. U. S. A., 60: 545 (1968). 
42. Sass, J. K., Itabashni, H. H., and Dexter, R. A.: Juvenile gout with brain involvement. Arch. Neurol., 13: 639 (1965).

43. Scherzer, A. L., and Irson, J. B.: Normal intelligence in the Lesch-Nyhan syndrome. Pediatrics, 44: 116 (1969).

44. Schulman, J. D., Greene, M. L., Fujimoto, W. Y., and SeegMiller, J. E.: Adenine therapy for Lesch-Nyhan syndrome. Pediat. Res., 5: 77 (1971).

45. Seegimiler, J. E., Rosenbloom, F. M., and Kelley, W. N.: Enzyme defect associated with a sex-linked human neurological disorder and excessive purine synthesis. Science, 155: 1682 (1967).

46. Sorensen, L. B.: Suppression of the shunt pathway in primary gout with azathioprine. Proc. Nat. Acad. Sci. U. S. A., 55: $571(1966)$.

47. Sorensen, B.: Mechanism of excessive purine biosynthesis in hypoxanthine-guanine phosphoribosyltransferase deficiency. J. Clin. Invest., 49: 968 (1970).

48. van der Zee, S. P. M., Lommen, E. J. P., Trijbels, J. M. F., and Schretlen, A. M.: The influence of adenine on the clinical features and purine metabolism of the Lesch-Nyhan syndrome. Acta Pediat. Scand., 59: 259 (1970).

49. van der Zee, S. P. M., Schretlen, E., And Monnens, L.: Megaloblastic anaemia in the Lesch-Nyhan syndrome. Lancet, $i: 1427$ (1968).

i0. Van Heeswujk, P. J., Blank, C. H., Seegmiller, J. E., and JAcobson, C. B.: Preventive control of the Lesch-Nyhan syndrome. Obstet. Gynecol. 40: 109 (1972).
51. Wada, Y., Arakawa, T., And Koizumi, K.: Lesch-Nyhan syndrome and in vitro study of incorporation of ${ }^{14} \mathrm{C}$-8-inosine into uric acid. Tohoku J. Exp. Med., 95: 253 (1968).

52. New England Nuclear Corporation, Boston, Mass.

53. P-L Biochemicals, Milwaukee, Wis.

54. Aldrich, Milwaukee, Wis.

55. Calbiochem, Los Angeles, Calif.

56. Packard Instrument Company, Downer's Grove, Ill.

57. Informed parental consent was obtained for experimental therapy which had been approved by the Human Subjects Committee, University of Wisconsin Mcdical School, in accord with the Declaration of Helsinki.

58. We thank Drs. James Anderson and Raymund Chun and Gail Tower, RPT, for assistance in patient care, Naomi Williams and Toni Paskey for skilled technical assistance, and the professional staff at Central Wisconsin Colony, Madison, Wisconsin for assistance in various aspects of this study.

59. Dr. P. J. Benke is a Special Postdoctoral Fellow, National Institutes of Child Health and Human Development.

60. This work was supported in part by Grant no. AM 13660, National Institutes of Arthritis and Metabolic Diseases, Grant no. CA-07175, National Cancer Institute, and Capitol City Chapter of the National Foundation.

61. Requests for reprints should be addressed to: PAUL J. BENKE, M.D., Mailman Center, University of Miami School of Medicine, Miami, Fla. 33152 (USA).

62. Accepted for publication April 2, 1973. 